\title{
MIDDLE EOCENE FORAMINIFERAL ASSEMBLAGES, WESTERN VENEZUELA
}

MORENO-VASQUEZ*, Joselys, Laboratorio Geológico, Corpoven, S.A., Puerto La Cruz 6023A, Venezuela; CANACHE, Maritza, Earth Sciences Department, Intevep, S.A., Apdo. 76343, Caracas 1070A, Venezuela; GALEA-ALVAREZ, Francia, Laboratorio Geológico, Corpoven, S.A., Apdo. 4326, Puerto La Cruz 6023A, Venezuela.

Studies of middle Eocene foraminiferal shales were carried out to the southeast of the Maracaibo Basin, and to the north and northeast of the Barinas Basin. These sediments range between 300 to 2600 feet and constitute the seal of the main reservoir in the basins. The objective was to document the assemblage variations within the interval assigned to the middle Eocene M. lehneri to $T$. rohri Zones.

The foraminiferal distribution in the southeast of the Maracaibo Basin was used as a pattern for assemblage comparison with the other basin. This allowed us to observe the presence or absence of genera from one area to the other. Uvigerina seriata, Lenticulina rotulata, Eponides bolivarensis and Cibicidina cushmani represent the characteristic biofacies of the middle Eocene Pauji Formation, Uvigerina being one of the most conspicuous benthics. Furthermore, planktonic foraminifers are common within the sequence and the most abundant are spinose acarininids and truncorotalids, with some species of Turborotalia, Globigerinatheka and Chiloguembelina. In general, paleoenviroments vary from middle-inner neritic at the base, to upper bathyal and outer-middle neritic at the top.

In the Barinas Basin the microfauna is quite different, uvigerinids are scarce but Nummulites (Paleonummulites) are very common. To the north (middle Eocene Paguey Formation), the faunas indicate shallower conditions and are less abundant and diverse. Quinqueloculina spp. and the ostracod Bairdia are common to the top. Most of the sediments of this area belong to the Nummulites biofacies; Lenticulina rotulata, Eponides and some Gyroidinoides are often the only specimens present within this biofacies. The planktonics Acarinina, Turborotalia and Truncorotaloides only occur at the base of the sequence but Chiloguembelina can be found throughout. The paleoenvironments vary from outer neritic at the base to inner neritic at the top. However, the foraminiferal assemblages to the northeast of the Barinas Basin (Guanarito area) are distinguished by the abundant and diverse planktonic foraminifers such as Truncorotaloides rohri, $T$. topilensis, Truncorotaloides spp., Globigerinatheka subconglobata, Turborotalia cerroazulensis, Globigerina senni, Acarinina spinuloinflata, and $A$. broedermanni, showing some similarity with those to the southeast of the Maracaibo Basin. Generally, benthic assemblages indicate paleoenvironmental conditions ranging from outer neritic-uppermost bathyal at the base and middle part of the section, to middle-inner neritic at the top. Eponides antillarum, Lenticulina sp., Cibicidina aff. cushmani, Textularia aff. saggitula, Nonion spp., Ammobaculites spp., Eggerella and Trochammina constitute the most common forms.

Since variations in occurrence and abundance of genera and species content were observed between both the benthic and the planktonic assemblages from the southeast Maracaibo and north - northeast Barinas Basins, factors such as sediment supply, nutrients, oceanic conditions, and the distribution of carbonate and siliciclastic sediments were interpreted as determinant for the faunal distribution. 